Teologia i Moralność, Volumen 13(2018), numer 2(24)

doi: 10.14746/tim.2018.24.2.9

ORCID: 0000-0002-3731-1203

PIOTR OLSZANOWSKI

Bydgoszcz

\title{
Poszukiwanie prawdy moralnej w życiu i twórczości Johna Henry'ego Newmana
}

Prawda zajmuje w życiu człowieka istotne miejsce, a sam człowiek wezwany jest do tego, aby odkryć jej pełnię. Pytania dotyczące prawdy i jej natury pojawiały się już w starożytności i nurtowały umysły najwybitniejszych filozofów, a później z całą konsekwencją wędrowały poprzez przestrzenie wieków aż ku nowożytności. Kwestia prawdy obecna jest w żywy sposób także w nauczaniu Kościoła, który w Katechizmie zaznacza:

Kościół, który jest „filarem i podporą prawdy” (1 Tm 3,15), zachowuje wiernie „wiarę raz tylko przekazaną świętym” (Jud 3). To Kościół zachowuje pamięć o słowach Chrystusa, to on przekazuje z pokolenia na pokolenie wyznanie wiary Apostołów. Jak matka uczy dzieci mówić, a przez to rozumieć i komunikować się, tak Kościół, nasza Matka, uczy nas języka wiary, by wprowadzać nas w rozumienie i życie wiary (KKK, nr 171).

Dyskurs na temat prawdy w kręgach teologicznych - w dużej mierze zapoczątkowany przez pytanie postawione Chrystusowi: „Cóż to jest prawda?” (J 18,38) - był słyszalny przez wieki i pozostaje aktualny także dla ludzi współczesności. Prawda jako obiektywna wartość jest niemałym wyzwaniem dla dzisiejszego człowieka mierzącego się ze szczególnym rodzajem kryzysu pojęciowego. „Współczesną kulturę cechuje bowiem nie tylko wieloznaczność wielu ważnych pojęć, ale także tendencja do ich redefinicji. [...] Nietrudno zauważyć, że zmiana znaczeń tych pojęć w istotny sposób wpływa na kształt życia moralnego jednostek i całych społeczeństw" (Wanat 2017, s. 53-54). Spoglądając na szeroką panoramę zmian zachodzących w świecie, Jan Paweł II 
wskazywał na swoistego rodzaju kryzys prawdy obiektywnej. Analizując to zjawisko, pisał:

Sens prawdy pod każdym względem uległ poważnemu zachwianiu. Wnikliwa obserwacja pozwala stwierdzić, że ostatecznie chodzi tu o kryzys metafizyczny. [...] Strapiony człowiek stawia sobie pytanie: ,kim w końcu jestem?” Obiektywne widzenie prawdy często jest zastępowane stanowiskiem subiektywnym, bardziej lub mniej spontanicznym. Moralność obiektywna ustępuje miejsca etyce indywidualnej, w której każdy zdaje się być sam dla siebie normą działania i godzi się na wymagania wierności wyłącznie wobec tej normy (Jan Paweł II 1982, s. 15).

Tego rodzaju postawa jest $\mathrm{w}$ dużej mierze przejawem nastawienia postmodernistycznego, które w swojej istocie skierowane jest ku odejściu od klasycznego rozumienia prawdy w znaczeniu veritas est adaequatio rei et intellectus ${ }^{1}$ (por. Wanat 2017, s. 54), czyli „prawda jest zrównaniem rzeczy i intelektu” (Tomasz z Akwinu 1999, s. 24). Pojmowana w tym kontekście „prawda jawi się jako wielkość formalnie względna, zakładająca zawsze jako warunek swej możliwości ontologiczną prawdę rzeczy, opartą na stwórczej znajomości Boga" (Demmer 1996, s. 12).

Obecny zakres debaty dotyczący pojęcia prawdy w jej znaczeniu obiektywnym może być różnie formułowany, choć na ogół spotyka się następujące koncepcje prawdy: klasyczną, koherencyjną, pragmatystyczną, deflacyjną oraz inne (Judycki 2001, s. 25). W tak zróżnicowanej oraz wieloaspektowej strukturze człowiek, aby odnaleźć swoją tożsamość i przebić się przez degradację pojęciową, potrzebuje jasnych znaków, które ukażą mu właściwy kierunek postępowania i odczytywania rzeczywistości w jej najgłębszym wymiarze. $\mathrm{W}$ tym znaczeniu prawda jawi się jako warunek sine qua non w odniesieniu do ludzi pragnących prowadzić swoje życie zgodnie z wymaganiami zapisanymi na kartach Ewangelii.

Poniższy artykuł podejmuje próbę przybliżenia prawdy w jej ujęciu moralnym na podstawie życia i twórczości wybitnego teologa, jakim był John Henry Newman. To postać, którą należy rozpatrywać jako jednego z najwybitniejszych myślicieli XIX wieku, wyjątkowego pisarza oraz wielkiego intelektualistę. Życie tego znamienitego człowieka wielkiego umysłu przepełnione było umiłowaniem prawdy, co wielu badaczy zamyka w kategorii pasji, podkreślając szczególnego rodzaju dyspozycję ukierunkowaną ku prawdzie. Temu, kto sięga po jego dzieła oraz spogląda na jego twórczość i koleje losu, daje się poznać jako gorliwy uczeń prawdy, który kochał ją ponad wszystko inne. Fascynująca historia wiary i odwagi angielskiego konwertyty kreślo-

\footnotetext{
${ }^{1}$ Sancti Thomae de Aquino, Quaestiones disputatae de veritate, q. 1 a. 1 co., w: Opera omnia, t. 22, red. Fratrum Praedicatorum, Rzym 1970, s. 3.
} 
na przez linie biegnące ku prawdzie, stała się wyznacznikiem wszelkich podejmowanych przez niego decyzji, a on sam do dziś stanowi inspirację dla wszystkich, którzy pragną kształtować swoje życie na fundamencie, jakim jest Prawda.

\section{Prawda moralna}

Gdy w kręgu dyskusji i rozważań pojawia się samo słowo prawda, to zdaje się, że w większości przypadków ogół zainteresowanych wie, co kryje się za znaczeniem pojęciowym tego wyrazu, stąd podejmowany trud rzetelnej analizy jest powierzchowny i nie wchodzi w głąb bogactwa kryjącego się pod warstwą konceptualnych uwarunkowań. Na takie ograniczenia nie może pozwolić sobie teologia moralna, gdyż z jej punktu widzenia tylko wytrwałość w poszukiwaniu jest czynnikiem warunkującym oraz gwarantującym dojście do zadowalających rezultatów. Skrupulatny postulat badawczy teologii moralnej domaga się, by przedmiotowi dociekań towarzyszyło niestrudzone zaangażowanie, naznaczone nieustępliwością. Wynika to z przekonania, że na poziomie teologii moralnej dotyka się realnych starań położenia solidnych fundamentów. To wszystko sprawia, że progres myśli teologiczno-moralnej jest ujmowany nie na zasadzie szybkości działania, a raczej dokładności i precyzji, dostrzegając odpowiednie rozstrzygnięcia z dalekiej perspektywy (por. Demmer 1989, s. 39-45), co odnosi się także w dużej mierze do prawdy moralnej.

Na samym początku warto zmierzyć się z niełatwym zadaniem, jakim jest zamknięcie prawdy moralnej w określonych granicach encyklopedycznej definicji. Choć wyzwanie to wymaga skrupulatnej pracy, to wcale nie oznacza, że tego rodzaju wysiłek nie został podjęty. Przeciwnie, w obcojęzycznej literaturze przedmiotu można znaleźć definicję włoskiego teologa Giuseppe Granerisa, który w odniesieniu do zagadnienia prawdy pisał, że z czysto moralnego punktu widzenia człowiek ma trzy obowiązki w odniesieniu do prawdy: akceptację, uaktywnienie i manifestację (por. Graneris 1962, s. 1247). Chodzi więc o przyjęcie prawdy przez osobę w całym jej wymiarze, urzeczywistnianie jej w perspektywie życia oraz danie świadectwa o niej w odniesieniu do zewnętrznej rzeczywistości.

Mimo pewnego światła rzuconego na poruszony temat wciąż pojawiają się pytania. Można je wyartykułować przy użyciu słów znanego teologa moralisty Klausa Demmera: „Czym jest prawda moralna, jak ją można odróżnić od innych prawd, od prawd faktycznych, od prawd filozoficznych czy teologicznych?” (Demmer 1996, s. 88), a odpowiedzi udzielić, odwołując się bezpośrednio do tych nakreślonych przez niego samego: 
Prawda moralna odwołuje się do swego adresata w całej jego rzeczywistości bycia człowiekiem, ponieważ w grę wchodzi życie w całym swym urzeczywistnianiu się: rozumnym i po ludzku godnym. Łatwo stwierdzić, że prawda moralna jest prawdą sensu, dostępną w rzeczywistości działania. Wynika z tego, że istnieje związek teologii moralnej z antropologią, jako że w centrum teologii moralnej znajduje się: właśnie człowiek, jego osobowa godność oraz to, jak ujawnia się ona i poświadcza w działaniu (Demmer 1996, s. 88).

Prawda w konotacji moralnej odsłania pragnienie przynależności do człowieka w całej jego aktualnej strukturze i kondycji, ujmując go w systemowej wizji holistycznej, gdzie poszczególne elementy składowe tworzą uniwersalny zbiór całości. „Prawda moralna dotyczy człowieka takiego jakim jest, we wszystkich jego wymiarach i relacjach, czy to wewnętrznych - jego duchowej dyspozycji (Gesinnung), czy to zewnętrznych - jego czynach" (Demmer 1996, s. 46).

Istotnym przymiotem prawdy moralnej jest również to, że nie może być ona w pełni odkryta jako prawda implikatywna, czyli związana tylko z głęboką rzeczywistością wewnętrzną. Nie jest z tych, które definitywnie tkwią w zamknięciu. Trzeba by raczej spojrzeć na nią z punktu widzenia eksplikatywnego i w tej kategorii ją osadzić, jest ona bowiem prawdą osiągalną w szerokiej perspektywie działania. Prawda moralna wymyka się i wykracza poza ujęcie immanentne, trudno mówić o niej jako o tej, która ma pełną niezależność bytową od czynnika zewnętrznego, gdyż swoje źródło ma w Tym, który jest „drogą i prawdą, i życiem” (J 14,6). Wychodząc poza i przekraczając zdefiniowane granice wewnętrzności, prawda moralna manifestuje swój charakter transcendentny:

Ujęcie myślenia transcendentalnego pozwala stwierdzić, że prawda moralna jest złączona z samozrozumieniem swego adresata, o ile otwarta jest na transcendencję. Prawda ta jest osiągalna przy pomocy analizy transcendentalnej, w której myślenie skierowane wyłącznie na obiektywność pozostaje nie wystarczająca z powodu jego wewnętrznych ograniczeń (Demmer 1996, s. 93).

W ujęciu optyki moralnej prawda nie jest pozbawiona swojej autonomii, chodzi bardziej o jej otwartość i dialogiczność na rzeczywistość poza podmiotem moralnym, szczególnie gdy w grę wchodzą prawdy natury antropologicznej. Istota moralna prawdy ujawnia się przez jej relacyjność w odniesieniu do całego człowieka z całym bagażem podejmowanych przez niego decyzji, prowadzonego postępowania i kroczenia drogą indywidualnych wyzwań. Jak podkreślają znawcy przedmiotu, ,jeśli moralista chce nadać swojemu myśleniu i argumentacji przejrzystość i powagę powinien interesować się wstępnymi decyzjami antropologicznymi" (Demmer 1996, s. 93). 
Temat moralnego charakteru prawdy został również nakreślony przez Jana Pawła II w encyklice Veritatis splendor, gdzie papież powoływał się na św. Tomasza z Akwinu, a zatem tego, „którego obdarzono w Kościele najbardziej zaszczytnym tytułem naukowym - Doctor Catholicus" (Andrzejuk 2000, s. 7). We wspomnianym dokumencie Jan Paweł II zaznacza, że „racjonalne skierowanie ludzkiego czynu ku dobru w jego prawdzie oraz dobrowolne dążenie do tego dobra, poznanego przez rozum - oto na czym polega moralność" (VS, $n r$ 72). Istotną cechą moralności prawdy jest jej odniesienie do dobra. Teologia moralna nie gubi z kręgu swoich zainteresowań jaśniejącej prawdy „o dobru doprowadzonym aż do doskonałości” (VS, nr 110). Łatwo zauważyć, że między prawdą a dobrem istnieje specyficzna relacja, która osadzona jest w kręgu moralności, zresztą możemy powiedzieć, że „moralne dobro tym się w całej gamie różnorakich dóbr wyróżnia, że dotyczy człowieka jako człowieka" (Kaczyński 2007, s. 5). W tym kontekście Jan Paweł II wskazywał, że „najwyższe Dobro i dobro moralne spotykają się w prawdzie" (VS, nr 99). Spotkanie tych dwóch wartości jest dokonywane w prawdzie Boga Stwórcy oraz w prawdzie człowieka (por. VS, nr 99), jeśli zaś dotyka się prawdy o człowieku, to trzeba mieć na względzie, że prawda moralna dotyka rzeczywistości człowieka w całej jego egzystencji i w odniesieniu do całej realności, co więcej wpleciona jest w historię życia z całą swoją niepewnością, zagadkowością, ryzykiem i wyzwaniami. Adresat prawdy moralnej wzrasta i dojrzewa poprzez jej poznanie. Poza tym prawda moralna wysuwa postulat współ-naturalności, co oznacza życie w niej jako odpowiedzialność za rzeczywisty personalizm (por. Demmer 1991, s. 22). Ujmując zagadnienie w innych słowach, można powiedzieć, że dla człowieka wybór prawdy moralnej i przylgnięcie do niej odbywa się w specyficznych warunkach hic et nunc jego istnienia, gdzie na widnokręgu króluje również dynamiczny dialog teologii moralnej z innymi naukami empirycznymi, interdyscyplinarne podejście czy filozoficzna wrażliwość. Wszystko to pozwala na zrozumienie złożonego i wieloaspektowego statusu epistemologicznego prawdy moralnej (por. Demmer 1991). Sama prawda ujawnia swój charakter dialogiczny, o czym przypomniał papież Benedykt XIV, pisząc:

Prawda to bowiem lógos, który tworzy diá-logos, a więc komunikację i komunię. Prawda, dzięki której ludzie wychodzą poza subiektywne opinie i odczucia, pozwala im wznosić się ponad uwarunkowania kulturowe i historyczne oraz spotykać na płaszczyźnie oceny wartości i istoty rzeczy. Prawda otwiera i jednoczy umysły (Benedykt XVI 2009, nr 4).

Ujmując rozważania papieża w perspektywie moralnej, można dojść do przekonania, że prawda ukazuje swoją wartość w relacji i dialogu, który pozwala na przekroczenie ram indywidualizmu i tendencyjności. Dodatkowo 
według współczesnych poglądów prawda moralna, o czym już wspomniano, jest ściśle powiązana $\mathrm{z}$ wizją życia ludzkiego, które jest w pełni doświadczone, to znaczy, że jest otwarta na obecność w aspekcie operatywności i działania (por. Demmer 1991, s. 11). Jak zauważa Klaus Demmer, prawda moralna jest szansą i unikalną możliwością uniknięcia pozostania w getcie (por. Demmer 1991, s. 22). Z kolei Karl Jaspers (1883-1969), który podjął próbę odbudowania warunków przywrócenia klasycznego paradygmatu, twierdzil, że prawda w swojej esencji odpowiada wszechstronności, postrzegał ją w kontekście dogłębnego i rzetelnego postępowania i w związku z tym twierdził, że stanowi narzędzie, które przekracza wszelkie horyzonty, w jakich konieczność sama się obiektywizuje (por. Jaspers 1995, s. 81). Według Jaspersa istotą nie jest samo posiadanie prawdy, lecz jej poszukiwanie (por. Jaspers 2003, s. 6). „Ostatecznie prawda moralna, o ile rzeczywiście wymaganie moralne wzywa do szacunku dla samych siebie, powinna gwarantować życie w pełni zrealizowane i mające sens" (Demmer 1996, s. 12). Chyba nie ma w historii Kościoła lepszego przykładu dociekliwych, rzetelnych i dogłębnych poszukiwań prawdy na płaszczyźnie życia moralnego niż te, które podjął znamienity angielski teolog John Henry Newman.

\section{Prawda moralna w życiu i twórczości Johna Henry’ego Newmana}

Życie i twórczość Johna Henry’ego Newmana z całą stanowczością oscylowały wokół pojęcia prawdy, jej umiłowania oraz niegasnącej pasji jej poszukiwań. Jeden z biografów angielskiego myśliciela, Juan R. Vélez, stwierdził, że Newman ,od wczesnej dorosłości, preferował prawdę jako powierzchowny pokój umysłu" (Vélez 2012, s. XVII). Niewątpliwie dążenie do prawdy to jeden z głównych przymiotów wielkiego angielskiego teologa, sama zaś jej kontemplacja była fundamentalnym nurtem jego zainteresowań. „O życiu Newmana nie da się zresztą mówić inaczej jak o drodze nieustannego poszukiwania, czego wyrazem stało się jego życzenie, by na nagrobku znalazł się napis: $E x$ umbris et imaginibus ad veritatem" (Skrzypczak 2010, s. 110) - spośród cieni i obrazów ku prawdzie. Jak celnie zauważa Avery Dulles, to epitafium trafnie podsumowuje zarówno dążenie Newmana do wyższego świata boskości, jak i jego głębokie poczucie nieuchwytności (por. Dulles 1990, s. 252).

Brytyjski myśliciel w swoich poszukiwaniach w pełni oddał to, co później w encyklice Fides et ratio pisał Jan Paweł II, wskazując, że „wiara i rozum są jak dwa skrzydła, na których duch ludzki unosi się ku kontemplacji prawdy" (FR, Wstęp). Newman podjął wyzwanie i sam przebył drogę, która stopniowo doprowadziła go „do spotkania z prawdą i do zmierzenia się z nią” (FR, nr 1). Zresztą kwestia prawdy w odniesieniu do osoby wielkiego uczonego powinna 
być ujmowana w kategorii jego indywidualnej pielgrzymki oraz refleksji nad przestrzenią życia. Jest to ujęcie ściśle nowotestamentalne, gdzie prawdę rozumie się „,W sposób głęboko osobisty” (Farrugia, O’Collins 2002, s. 140).

Egzystencjalny kierunek, jaki obrał angielski myśliciel, nie koncentruje się na określonej przestrzeni i czasie, ale zmierza daleko poza przyjęte granice czasowości. I chociaż jego poszukiwania można zamknąć w sprecyzowanych wymiarach przestrzeni czasu oraz miejsca, to wydaje się, że poważnym błędem byłoby pominięcie ich nieprzemijalnego przesłania. $\mathrm{W}$ odniesieniu do współczesnego człowieka da się zaobserwować nie tylko poważny kryzys jego tożsamości, poważne uchybienia można zauważyć także w odniesieniu do prawdy jako wartości obiektywnej. Mimo iż Newman żył w XIX wieku, jego dorobek intelektualny nie stracił aktualności; dotyczy to również kwestii tak fundamentalnej, jaką jest prawda w ujęciu moralnym. Życiowe nastawienie błogosławionego kardynała nie polegało „na zamknięciu się w swym własnym ja, lecz na otwarciu się [...] i na uległym zaufaniu Temu, który jest prawdą [...]. Droga życiowa Newmana ukazuje ścisły związek jednostkowego sumienia z obiektywną prawdą" (Skrzypczak 2010, s. 109). W swoich naukowych dociekaniach w odniesieniu do prawdy był bezkompromisowy, gdy pisał, że z całego serca pragnie prawdy i obejmuje ją wszędzie, gdzie ją znajduje (por. Skrzypczak 2010, s. 109). W swoich rozważaniach podejmował różne pojęcia prawdy, ale to prawda moralna zajmuje kluczową pozycję w naukowym dorobku błogosławionego konwertyty. W jednym ze swoich listów wyraził przekonanie, że prawda w znaczeniu moralnym „możliwa jest do osiągnięcia poprzez cierpliwe studium, spokojną refleksję, milcząco niczym rosa - chyba, że cudownie dana - a zdobyta jest przekazywana przez wiarę" (Newman 1979, s. 131).

Jednym z przewodników Newmana na drodze odkrywania znaczenia prawdy dla życia moralnego i życia w ogóle był Thomas Scott. W Apologii Newman pisał o nim z wielką estymą, uznaniem i szacunkiem:

Pisarz, który wywarł na mnie głębsze wrażenie niż jakikolwiek inny, i któremu (mówiąc po ludzku) prawie zawdzięczam moją duszę. Jest to Thomas Scott z Ashton Sandford. [...] podziwiałem jego pisma i [...] się nimi rozkoszowałem. Miałem już od pewnego chłopca jego Site prawdy i Eseje; jego komentarz kupiłem zaś jako student uniwersytetu. Jego odważne przeciwstawianie się światu i wielka niezależność umysłu uderzy, sadzę, każdego czytelnika dziejów i pism Scotta. Szedł on za prawdą, gdziekolwiek ona go prowadziła, zaczynając od unitarianizmu, a kończąc na gorliwej wierze w Trójcę Przenajświętszą. On jako pierwszy zakorzenił głęboko w moim umyśle tę fundamentalną prawdę religijną (Newman 2009, s. 58). 
Siła prawdy odcisnęła na duszy znakomitego myśliciela niezatarte piętno, stając się przy tym swoistego rodzaju bardzo osobistym itinerarium, jakie prowadziło Newmana po ścieżkach prawdy, za którą - podobnie jak Scott - podążał tam, dokądkolwiek go zaprowadziła, a doprowadziła go do pełni prawdy, którą odkrył w Kościele zbudowanym na fundamencie apostołów, wśród których Piotr wiódł prym. Thomas Scott to nie jedyny wzór, z którego czerpał Newman. Do jego konwersji przyczynili się w znacznej mierze ojcowie Kościoła, gdyż to na podstawie ich pism angielski uczony ugruntował swoje poglądy na temat korzeni Kościoła, odkrył świeżość oraz uczciwość wczesnego chrześcijaństwa (por. Geissler 2004, s. 3). Droga prawdy, którą cierpliwie i konsekwentnie podążał Newman, opierała się w dużej mierze na dociekliwym oraz dogłębnym stadium pism ojców Kościoła. Thomas J. Morris zaznacza, że „nie tylko zachwycały Newmana ich pisma, ale oni sami stali się jego przewodnikami, wzorami do naśladowania, prorokami prowadzącymi go w podróży wiodącej od skrajów sceptycyzmu aż do pełni prawdy w Kościele katolickim" (Norris 2014, s. 67). Koniec końców, w prywatnej korespondencji do Edwarda B. Puseya, błogosławiony kardynał wyraził najwyższą aprobatę spuścizny ojców, formułując ją w następujących słowach: „Ojcowie uczynili mnie katolikiem, a ja sam nie zamierzam odtrącać drabiny, poprzez którą wstąpiłem do Kościoła" (Newman 1901, s. 24). Według Newmana prawda ujęta w perspektywie moralnej wymaga uczciwości w postawie intelektualnej, gdyż odmawia ona „odkrycia swych tajemnic tym, którzy podchodzą do niej w inny sposób niż w pokornym i uniżonym duchu uczniów spragnionych wiedzy" (Newman 2000, s. 30). Żarliwy uczeń prawdy zgłębiający jej bezpośredni odcień moralny, wymagający od niego podjęcia zdecydowanych działań, nie był wolny od wątpliwości. Zmagał się z nimi, a swoją wewnętrzną walkę opisał, ujmując ją w następujących słowach:

Jeśli prawda jest realną obiektywną rzeczą i jeśli staje ona w obliczu osoby, wychowanej w systemie pozbawionym prawdy, [z] pewnością trwanie osoby pragnącej iść słuszną drogą, przy systemie niesłusznym i nieopuszczanie go, byłoby tym samym, co walka przeciw obiektywności Prawdy, prowadząc niejako do podejrzenia, że i jedna, i druga rzecz jednakowo się podoba naszemu Stwórcy (Newman 2009, s. 310).

Coraz silniejsze miał też przekonanie, że moralna i duchowa perfekcja, która wyraża się w świętości, jest o wiele ważniejsza niż doskonałość intelektualna. Niemniej jednak to pełnia prawdy odnaleziona w Kościele katolickim była główną przyczyną sprawczą jego konwersji, która nastąpiła w roku 1845. Na uwagę zasługuje jednak, że na drodze prowadzącej go ku prawdzie wcale nie był to łatwy do postawienia krok, przeciwnie, wymagało to od nie- 
go pełnego zaangażowania, wewnętrznej spójności i bezwarunkowego przekonania co do słuszności podejmowanego działania. Posłuszeństwo prawdzie wymagało od niego wielkiej ofiary, czyli porzucenia wszystkiego, co do tej pory stanowiło o jego mentalnym i osobowościowym bogactwie: stopnia naukowego, wielu przyjaciół oraz zawodu (por. Benedykt XVI 2011, s. 40). Jednak opuszczenie Kościoła anglikańskiego stanowi najlepszy dowód na to, że Newman konsekwentnie pielęgnował prawdę moralną w konkretnych decyzjach życiowych, a nie tylko o niej mówił czy też zapisywał rozważania naukowe o niej. W dość poetycki sposób ujął stan swojego umysłu po nawróceniu, pisząc:

Od momentu, kiedy stałem się katolikiem [...] nie miałem jakichkolwiek niepokojów umysłu. Miałem spokój i zadowolenie, nigdy też nie miałem ani jednej wątpliwości. Nie odczułem przy nawróceniu jakiejkolwiek zmiany intelektualnej czy moralnej, która by wywierała ucisk na mój umysł. Nie miałem więcej zapału, ale było to jak przybycie do portu po wzburzonym morzu. A moje szczęście $\mathrm{z}$ tego powodu trwa nieprzerwanie aż do dzisiaj (Newman 2009, s. 351).

Poznanie ujęcia moralnego prawdy, która się urzeczywistniła i przybrała realny kształt w życiu kardynała, dało mu spokój ducha i intelektu, a sama pasja do prawdy, autentyczne przylgnięcie do niej i uczciwość intelektualna okazały się nieodzowne w jego osobistej pielgrzymce. Papież Benedykt XVI podczas modlitewnego czuwania przed beatyfikacją Newmana podkreślił, że ,jeśli przyjęliśmy prawdę Chrystusa i dla Niego poświęciliśmy swoje życie, to nie może być rozdźwięku między tym, w co wierzymy, a sposobem, w jaki żyjemy" (Benedykt XVI 2010, s. 643). Ponadto papież przedstawił kilka bardzo interesujących uwag o prawdzie i życiu angielskiego teologa:

Newman $[\ldots]$ widział jasno, że nie tyle akceptujemy prawdę w akcie czysto intelektualnym, ile przyjmujemy ją w dynamice duchowej, która przenika do głębi naszej istoty. Prawda jest przekazywana nie jedynie przez nauczanie formalne, choć jest ono ważne, ale także przez świadectwo życia, przeżywanego integralnie, w wierności i świętości. Ci, którzy żyją w prawdzie i prawdą, instynktownie rozpoznają, co jest fałszywe i to właśnie jako fałszywe, wrogie pięknu i dobru, towarzyszącym blaskowi prawdy, veritatis splendor (Benedykt XVI 2010, s. 643).

Ponadto kardynał Newman jest przykładem człowieka, który był prawdziwym uczniem Chrystusa, wskazując, że ,miłe światło wiary prowadzi nas do urzeczywistnienia prawdy o nas samych" (Benedykt XVI 2010, s. 644). Ujął to w niezwykłej modlitwie, która dzisiaj należy do jednych z najbardziej znanych w chrześcijańskim świecie: 
Prowadź mnie, Światło, swą błogą opieką,

Światło odwieczne!

Noc mroczna, dom mój tak bardzo daleko,

Więc Ty mnie prowadź.

Nie proszę rajów odległych widoku,

Starczy promyczek dla jednego kroku.

[...]

Tyś zawsze trwało, gdym przez głuchą ciemność,

Przez bór, pustynię

Błąkał się dumny. O, czuwaj nade mną,

Aż noc przeminie,

Aż świt odsłoni te drogie postacie,

Którem ukochał niegdyś, którem stracił (Newman 1973b, s. 5).

Poprzez świadectwo swojego życia błogosławiony konwertyta prezentuje bezprecedensową jedność pomiędzy wewnętrznym przeświadczeniem, wyznawaną wiarą a całym swoim życiem i czynami, które podejmował. Ta egzystencjalna harmonia znajduje odzwierciedlenie w umiłowanej przez Newmana medytacji: „Bóg stworzył mnie, abym wypełnił dla Niego jakąś określoną służbę; powierzył mi jakąś pracę, której nie powierzył nikomu innemu. Mam swoje posłannictwo - mogę nigdy nie poznać go w tym życiu, ale dowiem się o nim w życiu przyszłym" (Newman 1973a, s. 13). Komentując te rozważania, papież Benedykt zdefiniował postawę Newmana jako „doskonały realizm chrześcijański [...], w którym w sposób nieunikniony przenikają się wiara i życie. Wiara ma przynosić owoce w przemianie naszego świata mocą Ducha Świętego, działającego w życiu i aktywności wierzących” (Benedykt XVI 2010, s. 644). Podkreślenie zgody i jedności w życiu wielkiego angielskiego uczonego jest odbiciem prawdy, która w konotacji moralnej „w swej istocie jest [...] promieniowaniem odwiecznej Mądrości Bożej” (VS, nr 95). Ponadto, gdy człowiek w swoich decyzjach oraz podejmowanych wyborach staje wobec Bożej mądrości, to w tym ,sensie moralne dobro lub zło pozostaje w związku z ostatecznym celem człowieka. Poprzez czyny, zależnie od ich moralnej wartości, człowiek przybliża się lub oddala od Boga - celu ostatecznego" (Moskal 1994, s. 137).

Całość wieloaspektowego oraz skomplikowanego wewnętrznego procesu ludzkiego życia w odniesieniu do prawdy można odnaleźć u Newmana i w jego nastawieniu oraz determinacji na drodze poszukiwań prawdy. Taka postawa obecna jest $\mathrm{w}$ jego życiu, jego działaniach oraz $\mathrm{w}$ jego dziełach. Bardzo trudno jest dostrzec u niego brak spójności czy choćby najmniejszy rozdźwięk pomiędzy wewnętrznym przeświadczeniem a zewnętrznym urzeczywistnieniem. Trudno jest także znaleźć jakikolwiek ślad świadczący o nie- 
spójności. Jest to możliwe, gdyż jego specyficzna postawa podążyła za decyzją przyjęcia konkretnej pełni prawdy reprezentowanej przez chrześcijaństwo. Po długiej podróży intelektualnej podporządkowanej prawdzie moralnej, którą rozpoznał w najgłębszym zakątku samego siebie, mógł powiedzieć:

Wyznaję, że zupełnie poddaję się jej roszczeniom. Wierzę w całość objawionego dogmatu tak, jak on był nauczany przez Apostołów, jak został przez nich przekazany Kościołowi i jak mnie jest przez Kościół obwieszczony. Przyjmuję go jako nieomylnie interpretowany przez tę władzę, której jest w ten sposób zlecony, i tym samym będzie w podobny sposób dalej interpretowany przez tę samą władzę aż do skończenia czasów. Poddaję się także ponadto powszechnie przyjętym tradycjom Kocioła, w których mieści się materia tych nowych definicji dogmatycznych, jakie się ustala od czasu do czasu, i jakie zawsze są szatą i ilustracją dogmatu katolickiego, jak on już został zdefiniowany. I poddaję się owym innym decyzjom Stolicy Apostolskiej, teologicznym lub nie, przez organy, przez nią samą ustanowione (Newman 2009, s. 366-367).

Wkład Johna Henry'ego Newmana w kwestię rozumienia moralnego wymiaru prawdy jest niepodważalny. Błogosławiony konwertyta nie tylko zajął się teoretyzowaniem oraz spisaniem swoich przemyśleń w bogatej spuściźnie naukowej, ale prawdę moralną uczynił nieodzowną częścią swojego życia, oscylującego wokół osobistej podróży i poszukiwań. Zresztą chęć przylgnięcia do prawdy nie pozostaje obca żadnemu człowiekowi, gdyż „każdy [...] nosi w sobie pragnienie tego, co bezwarunkowe i absolutne, pragnienie bezwarunkowej prawdy" (Ćmiel 2008, s. 114). Jego rozważania i wysiłki wskazują, że ,jako mężczyźni i kobiety, uczynieni na obraz i podobieństwo Boga, zostaliśmy stworzeni, aby poznać prawdę, odnaleźć w tej prawdzie naszą ostateczną wolność i spełnienie naszych najgłębszych ludzkich dążeń. Jednym słowem, mamy za zadanie poznać Chrystusa, który sam jest «drogą, prawdą i życiem» (J 14,6)" (Benedykt XVI 2010, s. 643).

Postać znakomitego angielskiego teologa, a przede wszystkim jego gorliwość w poszukiwaniu prawdy staje się wzorem dla ludzi XXI wieku, którzy często zagubieni w wielości proponowanych dróg potrzebują jasnych znaków. John Henry Newman nie tylko wyznacza kierunki prawidłowych poszukiwań, ale także daje świadectwo swojego życia jako potwierdzenie, że wieloaspektowy proces odkrywania prawdy jest możliwy do zrealizowania. Niezwykła charyzma i zacięcie są przykładem tego, jak uzyskać głęboki wgląd w siebie, by odnaleźć prawdę o swojej tożsamości. Tego rodzaju propozycja wyrafino- 
wanego podejścia do zagadnienia prawdy moralnej pozwala określić wielkiego angielskiego uczonego mistrzem i przewodnikiem życia moralnego. Jako gorliwy uczeń prawdy pokazuje, jak rozwijać i realizować pasję ku prawdzie.

\section{THE SEARCH FOR MORAL TRUTH IN THE LIFE AND WORKS OF JOHN HENRY NEWMAN}

\section{Summary}

Truth occupies an important place in human life, and man himself is called to discover its fullness. Questions about the truth and its nature already appeared in antiquity and were on minds of the most eminent philosophers and later they wandered with the whole consequence through the ages towards modernity. The question of truth is also present in the teaching of the Catholic Church.

The current debate in reference to the concept of truth in its objective meaning can be formulated differently. In a diverse and multifaceted structure, a person needs to encounter his identity and pass through conceptual degradation in order to find clear signs which will show him the right direction of acting and make him able to accept reality in its deepest dimension. In this sense, truth appears as a condition sine qua non for the people who want to live their lives according to the requirements of the Gospel.

The following article attempts to approximate the reality of truth in its moral perspective based on the life and works of an outstanding theologian, John Henry Newman. He is a character who should be seen as one of the greatest thinkers of the 19th century, an exceptional writer and a great scholar. The life of this great man was filled with the love of truth, which many researchers understand in the category of passion, emphasizing a special kind of disposition directed towards the truth. Whoever reaches for his academic works and looks at his intellectual output recognizes him as an ardent disciple of truth who loved truth above all else. The fascinating history of the faith and courage of the English convert has become a determinant of all decisions he makes, and he himself is still an inspiration for everybody who wants to form their lives based on the foundation of the Truth.

Keywords: John Henry Newman; truth; moral truth

Słowa kluczowe: John Henry Newman; prawda; prawda moralna 


\section{BIBLIOGRAFIA}

Andrzejuk A. (2000), Prawda o dobru. Problem filozoficznych podstaw etyki tomistycznej, Warszawa.

Benedykt XVI (2009), Encyklika o integralnym rozwoju ludzkim w miłości i prawdzie Caritas in veritate, Rzym.

Benedykt XVI (2010), Aktualność Newmana w obliczu kryzysu wiary, „Acta Apostolicae Sedis” 102 , s. 642-645.

Benedykt XVI (2011), Musimy trwać w wierze i czynić dobro, „Acta Apostolicae Sedis” 103, s. 33-41 .

Ćmiel H. (2008), Teologia moralna szczegółowa, Częstochowa.

Demmer K. (1989), Interpretare e agire. Fondamenti della morale cristiana, Cinisello Balsamo.

Demmer K. (1991), Statuto epistemologico della verità morale, w: La norma nella vita morale del cristiano, red. S. Ronca, Milan, 11-22.

Demmer K. (1996), Wprowadzenie do teologii moralnej, tłum. A. Baron, Kraków.

Dulles A. (1990), From Images to Truth: Newman on Revelation and Faith, „Theological Studies” 51, s. 252-257.

Farrugia E.G., O'Collins G. (2002), Leksykon pojęć teologicznych i kościelnych z indeksem angielsko-polskim, tłum. J. Ożóg, Kraków.

Geissler H. (2004), Exemplary Commitment to the Service of Truth, „L'Osservatore Romano” Tygodniowa edycja w języku angielskim 11/18, s. 3.

Graneris G. (1962), Truth, w: Dictionary of Moral Theology, red. H.J Yannone, Westminster - Maryland, s. 1247-1248.

Jan Paweł II (1982), Przemówienie Kultura i perspektywy przyszłości świata, „L’Osservatore Romano" 3 nr 5, s. 15.

Jan Paweł II (1996), Encyklika o niektórych podstawowych problemach nauczania moralnego Kościoła , Veritatis splendor”, w: Encykliki Ojca Świętego Jana Pawła II, t. 2, Kraków, s. 531$-637$.

Jan Paweł II (2003), „Fides et ratio”. Tekst i komentarze, red. T. Styczeń, W. Chudy, Lublin.

Jaspers K. (1995), Philosophy of Existence, thum. R.F. Grabau, wyd. 7, Philadelphia.

Jaspers K. (2003), Way to Wisdom. An Introduction to Philosophy, thum. R. Manheim, Yale.

Judycki S. (2001), O klasycznym pojęciu prawdy, „Roczniki Filozoficzne” 49, s. 25-62.

Kaczyński E. (2007), Prawda - Dobro - Sumienie. Z zagadnień teologii moralnej, Warszawa.

Katechizm Kościoła katolickiego (2009), wyd. 2, Poznań.

Moskal P. (1994), Bóg a moralność. Nad encyklika „Veritatis splendor”, w: U źródet tożsamości kultury europejskiej, red. T. Rakowski, Lublin, s. 136-138.

Newman J.H. (1901), Certain Difficulties Felt by Anglicans in Catholic Teaching, t. 1, London-New York-Bombay.

Newman J.H. (1973a), Nadzieja w Bogu Stwórcy, w: J.H. Newman, Rozmyślania i modlitwy, thum. Z. Kubiak, Warszawa, s. 13-14.

Newman J.H. (1973b), Prowadź mnie, Światto, w: J.H Newman, Rozmyślania i modlitwy, thum. Z. Kubiak, Warszawa, s. 5.

Newman J.H. (1979), To Jemima Newman (Oriel, March 13, 1829), w: The Letters and Diaries of John Henry Newman, t. 2, red. I. Ker, T. Gornall, Oxford, s. 129-131.

Newman J.H. (2000), Kazania uniwersyteckie, tłum. P. Kostyło, Kraków.

Newman J.H. (2009), Apologia pro vita sua, thum. S. Gąsiorowski, Warszawa.

Norris T.J. (2014), Kardynat Newman dzisiaj, thum. B. Moderska, Poznań.

Sancti Thomae de Aquino (1970), Quaestiones disputatae de veritate, q. 1 a. 1 co., w: Opera omnia, t. 22, red. Fratrum Praedicatorum, Rzym.

Skrzypczak R., Wznieśmy toast: za sumienie i za papieża!, „Fronda” 56 (2010), s. 106-113.

Tomasz z Akwinu (1999), Dysputy problemowe. O prawdzie, thum. A. Białek, Lublin. 
Vélez J.R. (2012), Passion for Truth. The Life of John Henry Newman, Charlotte - North Carolina. Wanat Z. (2017), Obrona życia ludzkiego jako kwestia prawego sumienia, „Teologia i Moralność” 22, s. 53-68.

Piotr Olszanowski - dr, kapłan diecezji bydgoskiej, absolwent Wydziału Teologii Moralnej Papieskiego Uniwersytetu Gregoriańskiego w Rzymie. W latach 2016-2018 jeden z wykładowców Wyższego Seminarium Duchownego w Bydgoszczy, gdzie prowadził wykład z zakresu teologii moralnej. Zainteresowania naukowe obejmują współczesne zagadnienia teologii moralnej fundamentalnej oraz szczegółowej, filozofii moralności oraz etyki. 